\title{
Initial Thoughts on Building Harmonious Labor Relations*
}

\author{
Xiaowen Zhu, Zhihong Zhang, Mingliang Zhang \\ Shandong Administration Institute, Jinan, China \\ Email: \{allay, mingliang1, zzhihong_3\}@126.com
}

Received October 4, 2011; revised November 27, 2011; accepted December 21, 2011

\begin{abstract}
Labor relation is an important relationship of the modern market economy, and harmonious labor relation is not only conducive to promote social harmony, but also the reflection of the core competitiveness of enterprises, which is also important to the value achievement of workers. Research on the conflicts of labor relations has increasingly presented the features of intervening from the perspective of human resource management. Based on this, this article puts special emphasis on the following three aspects to promote the establishment of harmonious labor relations: strengthen the position of the core indicators of employee satisfaction, design system of remuneration based on benefit-sharing, upgrade cost consciousness of related professionals.
\end{abstract}

Keywords: Labor Relations; Human Resource Management; Employee Satisfaction; Compensation

\section{Introduction}

Labor relations got much attention from researchers and managers, and the intensification of labor relations conflict has brought heavy pressure to the community and enterprises. As China's economy continuously transformed too rapidly, China's labor relations have been replaced by market-oriented labor relations, with the intensification of labor relations conflict, such as Foxconn incident, has caused widespread concern. In the context of continuous improvement in the quality of workers, simple and crude solutions cannot meet the needs of the times, therefore, how to properly deal with the conflicts of interest between employers and employees and to build harmonious labor relations has become an unavoidable reality question at the present stage of Chinese society.

1) Harmonious labor relations are a breakthrough in building a harmonious society. The core of harmonious society lay in the harmony among people. An investigation report of Tsinghua university has pointed out that our country was facing a number of social conflicts currently, and building harmonious labor relations was the key point to eliminate "power of evil", "capital of evil" represented by this trend and to resolve the imbalance in China's interest, and to establish the labor game mechanism.

2) Harmonious labor relations are the core competetiveness of enterprises. Labor relations are the most important relationship in the modern market economy, and harmonious labor relations are the request of the modern

*This research was supported by grants from the Soft Science Research Project of Shandong Province (2011-2012). market economy, which is essential for businesses to establish and maintain a sustainable competitive advantage. In order to gain a competitive advantage, enterprises will have to gain cost advantages and personnel advantages. The data have shown that China's current labor dispute cases were increasing at an annual rate of 30 percent, and labor conflict has become a key factor constraining the effective development of China's enterprises, and thus affected the social harmony [1].

3) Harmonious labor relations reflect the value pursuit of people-oriented. Premier Wen Jiabao pointed out, to let workers live in dignity. Not only enjoy equal freedom and rights authorized by the law and the Constitution, but also achieve their own comprehensive development under the conditions provided by the society, which including the power of obtaining wages and benefits, and the freedom of improving the living standards. And harmonious labor relations are based on the guarantee of the power of workers, and the achievement of the benefits.

\subsection{Literature Review}

There are actually two aspects of labor relations: one is the legal level, and the other is the management level. China has promulgated many laws to regulate labor relations, but the law cannot solve all labor disputes, so management-level communication and coordination become more humanization and more important. The labor relations conflict has been the direct research object of management theory since the beginning of the 19th century [2].

Modern western scholars believed that the key of labor 
relations conflict management was to improve the management level in three aspects: the management framework of the enterprise, the labor organization, and the specific policies and practices of human resource management [3]. Productivity improvements during Industrial Revolution benefitted directly from the findings of early management theory, in which Charles Babell proposed "profit-sharing plan" to resolve the labor relations conflict, and Taylor's scientific management theory suggested that employers and employees must be on a profound revolution of thinking, so that "both sides did not focus on the distribution of earnings, and did not regard the earnings distribution as an important thing” [4]. Mayo's behavioral science school discovered and confirmed that the morale of the workers had significant impact on production efficiency of enterprises.

While the human resources school considered that taking problem-solving tools jointly promoting and integration could effectively alleviate the labor conflicts, such as the wide use of the team [5]. Some scholars have stressed that in the era of knowledge economy, human resources management should vigorously promote the contribution of human capital to the organization [6]. Based on Fells (2003), Abbott (2007) further explored the specific content of the match between labor relations policies and human resource management practices, taking account of labor relations like labor standards, labor disputes, collective bargaining, labor welfare, occupational health and safety, etc. into various human resource management practices, accomplishing related labor relations functions through the practices of human resource management [7], such as the salary system, whether collective agreement signed by trade unions and the company, in which whether the clear salary criteria, such as minimum wage, etc.. Integration trends in the process of labor relations and human resource management in Western countries provided us good references.

\subsection{Current Situation of Labor Relations in China}

China's labor relations conflict has transited from the hidden tensions in the planned economy era to a dominant performance under the conditions of market economy. The formation of labor relations is increasingly marketoriented, while labor relations are becoming contractbased, in which, the workers' consciousness of protecting their right is growing, therefore the number of filing of collective labor disputes and the number of people involved maintain a high growth rate. However, it is still outstanding that workers are infringed.

Faced with this situation, China's scholars explore the solutions of labor relations conflict most from the outside level, and explore the construction issues of external mechanisms of labor relations, such as independent trade unions, collective bargaining, and government intervenetion etc. Many researchers tended to coincidentally mention the local government deviation to capital and longterm weak trade unions. Such as Zhou Daohua considered that local governments had some phenomena and problems of vacancies and dislocations in dealing with labor relations, and pursued public powers and policies of economic growth one-sided, which would make workers be in a more disadvantage status [8]. Foxconn employees continuous jumping events shocked the whole country, studying the deeper reason of which was the serious absence of social organization, "there is no routine system to maintain the power of social self-organization emerged in response to major social crisis" [9]. However, in the current political, social, and economic circumstances, these mechanisms are difficult to be quickly established and play an effective role. In the face of the reality of situations that the number of labor dispute cases received by local labor dispute arbitration institution had raised from 314,000 in 2005 to 690,000 in 2008, seeking to resolve labor conflicts from the enterprise have become a more practical way.

Domestic scholars have clearly pointed out that labor relations conflict was the biggest challenge of human resource management [10]. Concrete embodiments of human resources management are job opportunities, training and development, performance appraisal and other functional activities, but the final effect of the activities is the harmony of labor relations. Harmonious labor relations are also considered as the positive perception of staff's support to an organization. The main goal of human resource management is to organize the effectiveness or efficiency, and good labor relations environment could play an active role in organizational performance through the emotional commitment and job satisfaction [11].

Harmonious labor relations should be the basic objective of human resource management. China's human resources management has boomed since the 1980s, but there is great contrast between the advanced concept and practical effect: human resource management of the enterprises are using advanced means to circumvent the law in order to achieve low-cost strategy, which intensifies labor relations conflict, taking the "shortage of migrant workers" since the end of 2009 as an example, even if this problem occurred, in the eyes of many human resource managers, "migrant workers “ are still just "reservoirs", and are rarely mentioned to be treated using such basic evaluation like "staff satisfaction”.

\section{New Ideas of Building Harmonious Labor Relations}

In the construction of the road of harmonious labor rela- 
tions, there are three main aspects from the perspective of human resource management.

\subsection{Strengthen the Position of the Core Indicators of Employee Satisfaction}

Employee satisfaction is the measure standard of human resource management module (Gary Dessler, 2005). In the post set of human resources management system, director of labor relations is the most important position, and director of labor relations has been always the highest paid position of all human resources management system. However, human resource management has not been given due attention in our country, mainly because China's labor market has been a long-term state of oversupply, and the transfer of hundreds of millions of rural surplus labor makes low-cost strategies have a relatively large market. Under this low-cost strategy, China's human resources management under the two labor relations system pressure of lacking of "collective bargaining" and effective "method of protective labor legislation," has to stay in its initial stage, just being the department of hiring, firing, wages and benefits administration, and human resources management lost the dynamic role in building labor relations which it should have.

Employees would have a positive emotional response in the atmosphere of harmonious labor relations, and would produce a satisfactory mood to the work. So the employee will work harder when they have a high level of satisfaction, and identify the organization's values and goals. They will show positive work behaviors, so as to contribute to organizational performance. Improving job satisfaction could improve organizational performance, for which the functional activities of human resources should be aimed at this to do beneficial discussions.

\subsection{Design System of Remuneration Based on Benefit Sharing}

Benefit-sharing can greatly arouse the staff's enthusiasm to the work and loyalty to the organization, so as to facilitate the harmony and development of labor relations, so the salary system relates the core interests of laborers should reflect this characteristic.

An organization's compensation system has a longterm effect on its competitive advantage, and the development of effective reward systems can reduce costs and improve efficiency. In today's tight labor situation, the attractiveness of recruitment should be enhanced. Therefore, the organization should take different methods according to the different levels and types of staff in the setting of compensation. In the current practice of management, while the salaries of the enterprise core staff are generally adapt to the requirement of "people-oriented", labor conflicts concentrated more in the general staff level, whose wage-setting and wage adjustment periods often lags behind the employee needs, which often lead to contradictions. This has become the problem that must be taken seriously and solved by human resource salary management.

In addition, the focus of the current salary system is still a material reward. However, the structure of laborer's quality has changed. The culture quality of this generation of workers is improving continuously compared with workers of the last century, and their demands are also rising. According to Maslow's theory of hierarchy of need, we should pay more attention to workers' social needs, esteem needs and the need of self-realization etc., therefore, encourage elements within the organization have to follow the changes, such as job diversification, development (including job training and tuition sponsorship), quality of life (such as bus, flexible working hours, child care, etc.), the unique needs of individuals would arouse the enthusiasm of employees, and are more conducive to harmonious labor relations.

\subsection{Upgrade Cost Consciousness of Related Professionals}

One reason of the increase in labor dispute cases is the rising power awareness of workers. Workers are different from the past, whose human resource quality is improving, and rights awareness is increasing. They cannot be simply treated, and crude solutions will increase the labors' antipathies. At the same time, the processing capacity in labor dispute of small and medium-sized enterprise is relatively weak, which is often prone to various forms of the labor disputes, so the total cost is bound to increase.

The key to control the cost of management is management personnel. Therefore, human resource practitioners should improve the cost consciousness, and solve a variety of labor conflicts effectively in the actual management process, and promote an enterprise from enjoying transient benefit of "low-cost" strategy to the pursuit of innovation and development strategy.

\section{Conclusions}

In summary, harmonious labor relations can not only stabilize the society and ease conflicts, but also promote the national economy, and improve the security and motivation of ordinary workers, so the party and the government are exceptionally concerned about this issue. From the perspective of human resource management, it is a practical way to further promote the construction of harmonious labor relations, and to make up for the lack of legal means with the key indicators of human resources functional activities. 


\section{REFERENCES}

[1] Z. D. Huang and D. T. Yang, "The Integration of Human Resource Management and Labor Relations,” Modern Management Science, Vol. 27, No. 12, 2008, pp. 18-20.

[2] M. Li and T. Zhang, "Review on Management Research of Western Industrial Relations Conflict,” Journal of South China University of Technology (Social Science Edition), Vol. 4, No. 3, 2002, pp. 45-49.

[3] M. Barrier, "Putting a Lid on Conflicts," Nation's Business, Vol. 86, No. 4, 1998, pp. 34-35.

[4] C. George Jr., “The History of Management Thought," The Commercial Press, Beijing, 1985.

[5] Z. Y. Zhang and S. M. Zhao, "Discussion on the Labor Conflict Rooted in the Solution under the View of Industrial Relations and Human Resource," Foreign Economics and Management, Vol. 30, No. 10, 2008, pp. 32-38.

[6] S. Zhao, “Application of Human Capital Theory in China in the Context of the Knowledge Economy,” The Interna- tional Journal of Human Resource Management, Vol. 19, No. 5, 2008, pp. 802-817. doi:10.1080/09585190801991145

[7] Z. D. Huang and D. T. Yang, "The Integration of Human Resource Management and Labor Relations,” Modern Management Science, Vol. 27, No. 12, 2008, pp. 18-20.

[8] D. H. Zhou, "The Harmony between Government and Labor Relations,” Fujian Forum (Humanities and Social Sciences Edition), Vol. 26, No. 2, 2006, pp. 134-137.

[9] Social Development Research Group of Department of Sociology of Tsinghua University, "The Road toward Social Reconstruction,” Jinan Times, Jinan, 2010-09-16.

[10] K. Chang and W. Z. Tao, "Human Resource Management and Labor Relations Adjustment," Human Resource Development, Vol. 20, No. 8, 2006, pp. 4-9.

[11] Y. Z. Jiang, "The Analysis of Impact of Organizational Relations Climate on Organizational Performance,” Theory and Reform, Vol. 23, No. 1, 2010, pp. 84-87. 